\title{
Praxeological ethics as an element of organizational culture of functionals of the Near-Oder Boarder Guard Unit
}

\author{
LILLA MŁODZIK ${ }^{1}$ \\ University of Zielona Góra, Institute of Political Science
}

\begin{abstract}
Border Guards play an important role in Poland's security system, protecting its borders. For this purpose it needs to cooperates with the environment. Its areas cover many aspects in which organizational and interorganizational relationships are required. The basis of the mentioned relations are organizational and legal conditions, but their development are among others elements of organizational culture. It constitutes, according to the author, a collection of values, norms, attitudes, beliefs shared by the officers about the necessity of interaction and cooperation that define their behaviour, generate and increase cooperative competences and reinforce the sense of identity and professional community in achieving goals.

In the praxeological ethics approach proposed in the article, the actions of Border Guards are inextricably connected with ethical principles considered in terms of professional roles. Ethical-oriented management should constitute a source of cooperative advantage leading to a more efficient achievement of goals. It is based on the premise of creating relationships, whose rationale is the preference for joint actions in the public interest and for the common good.

This paper makes a difficult, due to the character of the problem, often based on unconsciousness of behaviour, attempt to investigate the dependence of the mentioned variables - effectiveness of cooperation and principles of professional ethics. The following research techniques were used in the quasi-comparative method: questionnaires, document analyses, casual interviews, unclassified observations and shadowing. For the surveyed whose knowledge and adherence to ethical principles is important in the group in practice, the degree of achievement of goals increases, but to a certain point.
\end{abstract}

Paper type: research article

Keywords: praxeological ethics, organizational culture, cooperation, service ethos, border guard

1 lilla-mlodzik@wp.pl 


\section{Introduction}

Praxeological understanding of an organization gains significant meaning in the case of public institutions. The assessment of their efficiency and effectiveness requires, with full certainty, an interdisciplinary approach combining economic as well as sociological and psychological aspects. The use of the achievements of praxeology in public management results from the fact that both these fields concern human activities, and praxeology is a more general science and points to ways to improve all activities, including in the public sphere. The activities of public organizations and their achievements are not the source of interest of their participants but also the citizens. Positive cooperation is linked with collective organized action, cooperation (Kożuch, 2011; Mises, 2007). Obligatory cooperation results from, as claimed by Kożuch (2011, p. 224), the nature of public institutions. It allows to increase the possibility of providing public services.

All the objectives and tasks within the organization should be subordinate to the overall goal which is serving the public through permanent fulfilment of public needs. This is possible only through cooperation. What is more, public organizations can associate mainly with legal regulations, a high degree of hierarchy and excessive formalism (Kieżun, 2005; Sułkowski, 2015; Szaban, 2011). Can they be managed more efficiently? If a concept based on cooperation is used as a tool to understand their development processes, the answer to the posed question should be found. The ability to cooperate, in public service (service), decides on obtaining many benefits that would not have been achieved e.g. without such cooperative advantage (Huxham, 1996; Kożuch, 2004, 2011; Lank, 2007). It is based on the occurrence of privileged relationships. At that time, intangible variables will come to the forefront, and the cooperation itself should be treated as a kind of value, contributing to a more effective realization of organizational goals and creating a specific organizational culture, a culture of cooperation, and thus development of the whole organization. Hence, the approach to efficacy as praxeological ethics proposed in the article, whose attempt to investigate is fraught with a large error resulting from the complexity of the problem. Nevertheless, it was undertaken, of course, in a fragmented scope.

\section{Praxeological ethics in the context of organizational culture}

According to Ciborowski (2010, p. 6), praxeological ethics refers to the effectiveness which is targeted and in accordance with the rules of professional ethics. Therefore, ethical factors are necessary in this area. In such a situation, effectiveness of performance should be understood as fulfilling the "triple E" criterion (effectiveness, economics, ethics) (Gasparski, 2000; Kieżun, 2005), with particular regard to the latter. Firstly of all, effectiveness meaning efficacy referring to the outcome of actions. 
Secondly, economics referring to the course (process, progress) of the activity. Both criteria must be in line with public needs. Kożuch (2015), introduces the notion of "sustainable performance" relating to the realization of specific objectives, in line with the final result - public needs. Therefore, there is no risk of setting a target that does not meet these needs. Thirdly, ethics, and more specifically moral values defining the framework (norms) of activities in a given culture, shaping professional ethos.

It is important to introduce a distinction between public activities (service) from human activities in general, which have been identified as serious activities. It eliminates the risk of establishing an incorrect goal that is not in line with real needs, and gives the seriousness and necessity of treating the goal of action seriously and with total responsibility, both its cognitive value - knowledge and praxeology - increase of knowledge through achievement of goals. The seriousness of activities in question requires taking into account a social axiological context from which obtaining (or not) permission to perform an effective action depends. Therefore, in this context, the evaluation of action depends precisely on the third "E" - from ethical elements. In analysing values and ethical standards, as Rostkowski (2012, p. 150) states, those "shared with society" should be the most important (at a higher level than in commercial enterprises), not so much through procreation and realization but by promoting them in society and enforcement with greater decisiveness. For the author, from the point of view of research (service) of officers, it is important to take into account the character of a particular profession in a cultural context $\mathrm{t}^{2}$ (Hofstede, 2000) - professional ethos, containing the most important basic assumptions, moral values and norms and personal and moral characteristics reflecting the layer of correlates and external manifestations. It should be borne in mind in the aspect of ethical legality that a number too big, rigor and detail of regulations (regarding e.g. artefacts) can cause a decrease in efficiency as a result of reformulation. It is also related to the so-called high ethical culture negatively coupled with the number and rigidity of legal norms (Nowak, 2009, p. 42).

\section{Functioning of the Border Guard in Poland}

The Border Guard was set up by the Border Guard Act of 12 October 1990 (Act, 1990) (hereinafter referred to as the SG Act), and began functioning on 16 May 1991 with the dissolution of the Military Border Guard. This organization is also the heir of the institutions of the interwar period - the Border Defense Corp and Border Guard.

2 According to Hofstede (2000), the culture shape of organizations is directly influenced by four dimensions of cultural differences in the national "background."

Praxeological ethics as an element of organizational culture of functionals of the Near-Oder... 
The Border Guard (hereinafter referred to as BG) is a unified uniformed and armed formation designed to protect the state border on land and at sea and control border traffic being a part of state-type special administration (Act, 1990, Article 1.1). In 2016 the tasks entrusted by the Border Guard legislator were carried out by nine units of the BG, employing a total of 14340 officers (The Border Guard in the number, 2016):

- Warmińsko-Mazurski Department of Border Guards with headquarters in Kętrzyn,

- Podlaski Department of Border Guards with headquarters in Białystok,

- Bieszczadzki Department of Border Guards with headquarters in Przemyśl,

- Śląsko-Małopolski Department of Border Guards with headquarters in Racibórz,

- Near-Oder Border Guards Department with headquarters in Krosno Odrzańskie,

- Sea Department of Border Guards with headquarters in Gdańsk,

- Nadwiślański Department of Border Guards with headquarters in Warszawa,

- Nadbużański Department of Border Guards with headquarters in Chełm,

- Karpacki Department of Border Guards with headquarters in Nowy Sącz.

The Near-Oder Border Guard Unit (hereinafter: NoBGU), with headquartered in Krosno Odrzańskie, is one of the nine divisions, carrying out organizational tasks determined by the legislator, protecting the state border with Germany and the Czech Republic. This branch was set up by the Regulation of 28 April 2009 (the Ordinance of the Ministry of Interior and Administration, 2009) in place of the Lubuskie Border Guard Unit and was established on 1 June 2009. As a result, all the tasks of the Lubuskie Border Guard Unit were taken over by a new unit, which was the beginning of a reorganization across the western border. On 1 October 2009, the Zgorzelecki and Bolesławski counties (Dolnoślaskie Voivodship) became part of the territorial scope of the NoBGU operation, after the Łużycki BGU was dissolved. Then on January 1, 2010, the Near-Oder Border Guard Unit in Krosno Odrzańskie expanded its territorial coverage by a part of the Zachodniopomorskie Voivodeship. However, this change turned out to be temporary. On 15 October 2013, the Maritime Border Guard Unit in Gdańsk took over outpost in Szczecin with its territorial coverage. From November 16, 2013, after the inclusion of all Dolnośląskie Border Guard Offices, i.e. institutions in Kłodzko, Jelenia Góra, Legnica and Wrocław-Strachowice, NoBGU covers the three voivodships with its reach: lubuskie, wielkopolskie and dolnośląskie. It is responsible for $716 \mathrm{~km}$ of the state border, including just over $347 \mathrm{~km}$ with the Federal Republic of Germany and $438 \mathrm{~km}$ with the Czech Republic. Territorial changes of NoBGU influenced the current shape of the formation reach (Figure 1).

The main organizational unit of the command department is the one headed by particular unit governors. Within the department there are sections functioning 


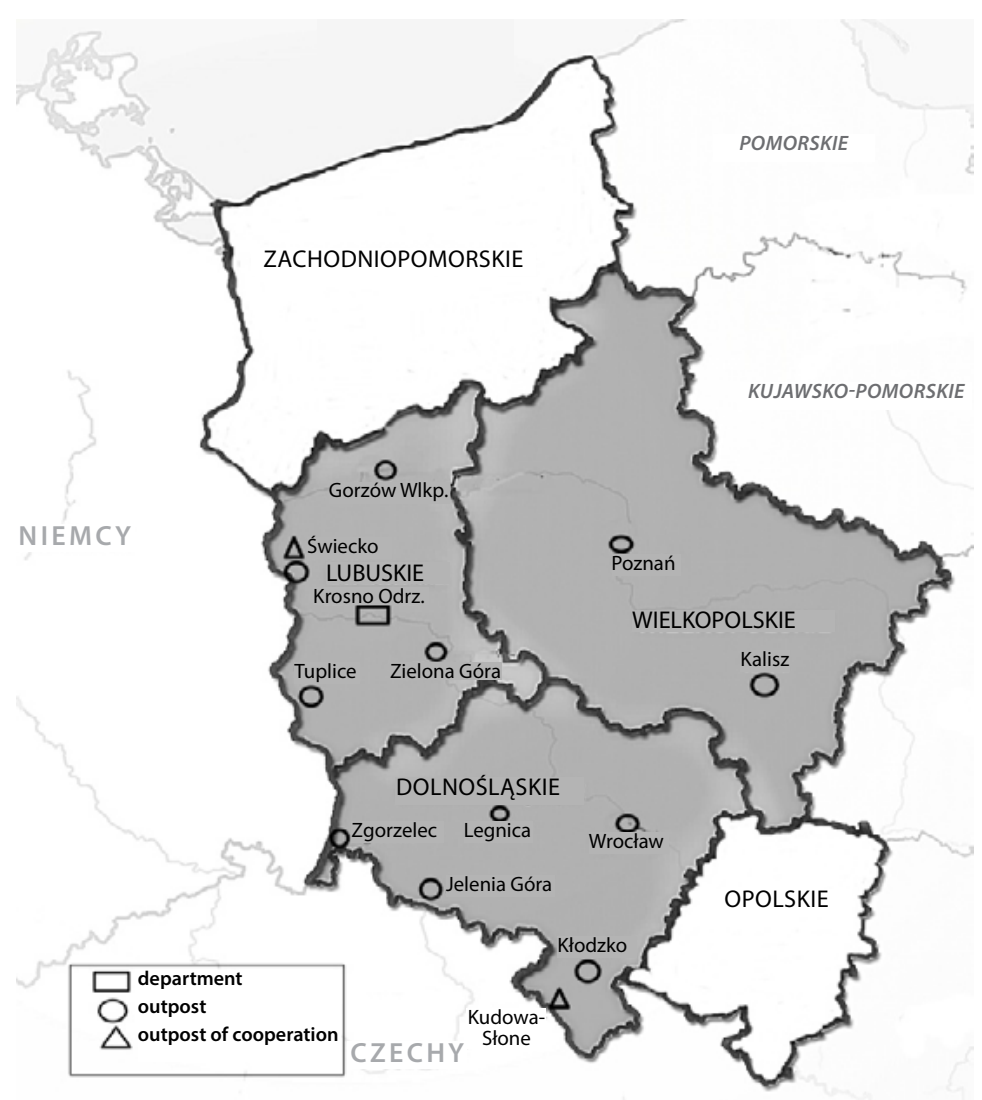

Figure 1. Near-Oder Border Guard Unit with its registered office in Krosno Odrzańskie.

(composing of several or dozen or more people with a manager at the head). The structure consists of (Edict, 2014):

- Operations and Investigation Department,

- Border Department,

- Department for Foreigners,

- Department of Communications and Computer Science,

- Department of Technology and Supplies,

- Department of Analysis, Information and International Cooperation,

- Department of Human Resources and Training,

- Department of Information Protection,

- Department of Coordination Activities,

- Department of Action Security,

- Control Department,

- Chief Accountant Division,

- Guarded Centre for Foreigners, 
- Team of Independent Post,

- NoBGU Health Service,

- Internal Audit Team.

The branch command is governed by the following NoBGU Outpostes (hereinafter: $\mathrm{OBG}$ ), led by individual commanders:

- OBG in Tuplice,

- OBG in Kalisz,

- OBG in Gorzów Wielkopolski,

- OBG in Zielona Góra-Babimost,

- OBG in Zgorzelec,

- OBG in Świeck,

- OBG in Poznań-Ławica,

- OBG in Wrocław-Strachowice,

- OBG in Jelenia Góra,

- OBG in Kłodzko,

- OBG in Legnica.

Service in the institution is held in groups and subordinate teams and lectures, separated by a range and span of management, adequate to the departments of the unit, headed by a manager. Each institution employs a varying number of officers (from a dozen to several dozen), depending on its location, tasks and needs. Often, depending on the situation, the service takes place in interdisciplinary teams consisting of officers of different groups. Therefore, officers are "forced" every day to cooperate and should be assessed for it. In the service of the NoBGU, similarly to other branches, the essence of the smooth execution of tasks are processes of interaction and the types of behaviour associated with them.

Border guard participates in many interactions with the environment. In the scope of cooperation, it creates inter-organizational relationships with various elements (organizational) belonging to the safety management system, being the sum of the activities of public administration, specialized intervention units, prosecutors, police, courts and other services, non-governmental organizations, private and those of the society, individual citizens (Kożuch \& Sienkiewicz-Małyjurek, 2013; SienkiewiczMałyjurek, 2015). The existing premises for inter-organizational cooperation are closely linked to the need for cooperation within the organization itself. It seems that, as the complexity of processes in the environment increases, internal, group and intergroup cooperation is becoming more important, based on building relationships that are necessary to respond appropriately to unexpected opportunities and threats.

Creating the proper conditions for the implementation of the principles of efficient operation requires an analysis of the existing functioning of the institution. In this process, chief executives, but also executive officers, should participate. Management must be convinced that its role is primarily to involve its subordinates in the process of participation. Every institution that wants to be successful and serve the society well, including border guards, must make many changes and surrender 
to them. It has to improve to become a dynamic, flexible and creative organization responsive to the needs of society. Every introduction of changes causes a variety of resistance, resulting both from the organizational structure, lack of resources, and the stereotypes of thinking and the resulting behaviour of people. Overcoming psychosocial barriers requires specific skills. The majority of theorists and management practitioners believe that in many cases the way to achieve the goals in an organization (while at the same time solving problems) is teamwork (Herman, Oleksyn, \& Stańczyk, 2016; Sikorski, 2014). In a special type of organization such as border guards, it is of particular importance. Collaboration is a value that promotes the realization of goals, and is a constitutive feature of institutions of this type.

\section{Research methodology}

The purpose of the research was to identify the area of organizational culture, including the relationship between professional ethics and the effectiveness of cooperation in the selected border guard units. The research was carried out in 2016, in all twelve organizational units of the Near-Oder Border Guard Unit, including: five in the Lubuskie Voivodeship (four border guards - including the Polish-German border crossing in Swiecko and the branch command), two from the Wielkopolska Voivodeship (at the airport of Poznań-Ławica) and five from the Dolnośląskie Voivodship (including Zgorzelec - on the section protecting the section of the Polish-Czech and Polish-German state border and the Wrocław-Strachowice Airport).

A quasi-comparative method was used. The selection of objects for research was based on determining comparable communities and objects in these communities. A collection of officers from all organizational units of the NoBG was accepted as a general community. The compared collectivities were communities of officers of these units, while the objects in those collectivities - teams of officers. The following research techniques were used in the above mentioned method: questionnaires, document analyses, casual interviews and uncategorized observations. Shadowing techniques are not excluded.

The research covered 390 officers, ${ }^{3}$ according to the selection of the sample. Groups of employees were selected according to the number of officers in the organizational unit. The study covered $30 \%$ of the officers of the entire unit. The percentage distribution of respondents in individual organizational units ranges from $1 \%$ to $21.9 \%$. The study was conducted in structures employing a different number of officers. This is conditional on the location of the units and the scope of their responsibilities. From a dozen to about one hundred eighty people work at the branch

3 The study covered both women and men. In the analysis of the research results, only for simplicity, the term: "officer" is used.

Praxeological ethics as an element of organizational culture of functionals of the Near-Oder... 
offices. The exception is the branch office in Krosno Odrzańskie, employing the largest number of officers (Table 1).

The empirical analysis of the social category comes from the different social backgrounds of the three voivodships mentioned. They are linked with common service in border guards, and differentiated by the specificity of the organizational unit: the number of officers employed in the unit, the number of people in the unit, and the characteristics of the officers, among others: degree in the corps, service experience, total seniority, education, gender, place of residence. Respondents were not analysed in terms of the specificity of the unit in which they serve, as a common denominator assuming the category "officer."

Table 1 Selection of respondents for the study

\begin{tabular}{|c|c|c|c|c|}
\hline No. & Voivodship & $\begin{array}{l}\text { Number of officers in the struc- } \\
\text { ture }\end{array}$ & Number of chosen officers & $\%$ \\
\hline \multirow{7}{*}{1} & \multirow{7}{*}{ Lubuskie } & up to 20 people & 4 & 1.0 \\
\hline & & from 21 to 40 people & 10 & 2.6 \\
\hline & & from 41 to 60 people & 15 & 6.3 \\
\hline & & from 61 to 80 people & 15 & 3.7 \\
\hline & & from 81 to 100 people & 18 & 4.6 \\
\hline & & from 101 to 130 people & 40 & 6.2 \\
\hline & & above 130 people & 86 & 21.9 \\
\hline \multirow{7}{*}{2} & \multirow{7}{*}{ Dolnośląskie } & up to 30 people & 11 & 2.8 \\
\hline & & from 31 to 50 people & 15 & 3.9 \\
\hline & & from 51 to 70 people & 21 & 5.3 \\
\hline & & from 71 to 100 people & 23 & 5.9 \\
\hline & & from 101 to 130 people & 31 & 8.0 \\
\hline & & from 131 to 150 people & 38 & 9.8 \\
\hline & & above 150 people & 58 & 14.8 \\
\hline \multirow{2}{*}{3} & \multirow{2}{*}{ Wielkopolskie } & up to 20 people & 4 & 1.1 \\
\hline & & from 21 to 60 people & 9 & 2.1 \\
\hline \multicolumn{3}{|c|}{ Total: } & 390 & 100.0 \\
\hline
\end{tabular}

Depending on the size of organizational units, empirical analysis covered employee groups of officers amounting from a few to a dozen or more persons. The largest number of six- and seven-person teams was examined - most often found in organizational units of the Near-Oder Border Guard Unit.

The following tools were used in the study:

a) in the case of effective cooperation:

- scale of generalized self-efficacy in the group - GSES (the General Self-efficacy Scale) (Schwarzer, Jerusalem, \& Juczyński, 2009). It consists of ten statements that form one factor. The scale measures the strength of a person's "soft power" as to the effectiveness of coping with difficult 
situations and obstacles. A feeling of self-efficacy allows predictions of intentions and actions in different areas of human activity, including in a group,

- questionnaire questions regarding the effectiveness of cooperation in quantitative and qualitative terms: joint actions, involvement in action, responsibility, character of relations, professional development,

- uncategorized interview,

- observation,

b) with respect to the principles of professional ethics:

- own scale of professional ethics - defining their knowledge and compliance resulting from documents (vows, ethical codes, specific personal-moral characteristics of officers) surveys and observation.

When analysing the empirical relationships between the variables tested, the following indicators were adopted (Table 2).

Table 2 Variables and their indicators

\begin{tabular}{|l|l|}
\hline \multicolumn{1}{|c|}{ Variable } & \multicolumn{1}{c|}{ Variable indicator } \\
\hline $\begin{array}{l}\text { Principles of pro- } \\
\text { fessional ethics }\end{array}$ & $\begin{array}{l}\text { Familiarity and observance of professional ethics in accordance with the regulation } \\
\text { of the Chief of the Border Guard on the professional ethics of officers of the BG. } \\
\text { Applying the principles of ethics on duty. } \\
\text { Observance of professional ethics outside service. } \\
\text { The opinion of the group is positive and membership is prestigious. } \\
\text { Understanding the meaning of public service as a profession of public trust. } \\
\text { Trying to make the opinion about the professional group as good as possible. } \\
\text { Caring for the exterior appearance. } \\
\text { Representing institutions in social and sports events. }\end{array}$ \\
\hline $\begin{array}{l}\text { Efficiency of } \\
\text { cooperation }\end{array}$ & $\begin{array}{l}\text { Officers have a sense of self-efficacy. } \\
\text { Meetings are held to exchange views, information. } \\
\text { Programs are being prepared together (preventive, information, intervention). } \\
\text { Programs are actively implemented (preventive, information, interventions). } \\
\text { Common training is often held. } \\
\text { The time of leading joint action in case of a specific threat is very important. } \\
\text { There are teams, committees dealing with security issues. }\end{array}$ \\
\hline
\end{tabular}

There are a few comments to be added. Development scales were used, the essence of which is the assumption that the overall feature and its more specific aspects develop in a continuous manner on a certain continuum, but for practical reasons one can distinguish some stages of this process that are similar to normal distribution (Filipowicz, 2016, p. 53). Moreover, the interval scale proposed for the study of praxeological ethics was used. It should be noted, however, that there may also be such results of respondents whose compliance with ethical principles can be treated in a fragmented manner due to situational context. Admittedly, research tools have been adapted (to obtain behavioural results also observed), but this cannot be ruled out. Perhaps this is the source of such, and not different results. 


\section{The effectiveness of cooperation and the principles of professional ethics of officers - results of research}

The chi-square test and correlation coefficients (Phi, Lambda, v-Kramer, tauGoodman and Kruskal, d-Somers, tau-b-Kendall, Spearman' correlation) (Górniak \& Wachnicki, 2000) were used in the analysis (Table 3).

Table 3 Effectiveness of cooperation and principles of professional ethics

\begin{tabular}{|l|c|}
\hline \multicolumn{1}{|c|}{ Factor } & Value \\
\hline Lambda & .886 \\
\hline Tau & .850 \\
\hline d-Somers & .678 \\
\hline Phi & .632 \\
\hline v-Kramer & .632 \\
\hline Tau b & .678 \\
\hline Spearman' corrlations & .447 \\
\hline
\end{tabular}

The results of cross-correlations between principles of professional ethics of the investigated officers and their effectiveness of operation are as follows: for those for whom knowledge and respect for professional ethics is relevant in the group in practice, the degree of achievement of the objectives pursued increases, but to a certain point. After reaching the maximum, with the increase of professional ethics indicators, the efficiency of cooperation decreases (Figure 2).

The research reveals that despite the increase in the attendance rate of indicators related to professional ethics, respondents indicate that they are worse off in achieving common goals. The results reveal that the investigated officers have a problem with the implementation of all possibilities connected with ethical elements. They perform their tasks best behaving in accordance with expectations. It results that perhaps these principles are imposed on them by commands and instructions, and their construction (mainly by proscriptive means, absolute prohibitions and injunctions) provokes nervousness and uncertainty in order not to commit an error, threatened with punishment, and this may result in the decrease of the degree of task implementation. This is also confirmed by the results of self-efficacy, as in this case, the mean values obtained are below the average (4 sten per standard). ${ }^{4}$

4 The sten scores (standard ten) - a scale of a psychological test normalized so that the average in the population is 5.5 , and the standard deviation is 2 . The scale has 10 units, average $=5.5$ (between 5 and 6 sten) (Juczyński, 2000). 


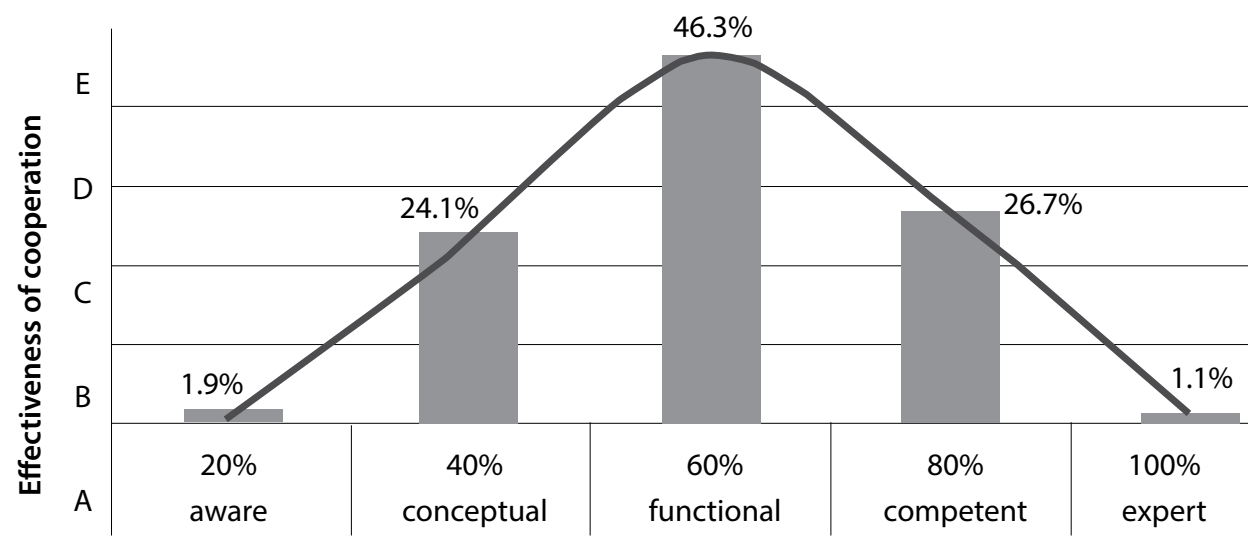

Rules of professional ethics

\section{Legend}

\section{Efficiency of cooperation:}

A - does not achieve results in cooperation,

$\mathrm{B}$ - achieves the intended result in cooperation with the help/support of others,

$\mathrm{C}$ - achieves the intended result in cooperation with commitment,

$\mathrm{D}$ - achieves the intended result in cooperation actively, despite non-standard circumstances,

$\mathrm{E}$ - exceeds the intended result in cooperation actively, despite non-standard circumstances.

\section{Principles of professional ethics:}

- aware - is aware of how he should behave,

- conceptual - knows how to behave - does not always succeed,

- functional - behaves as expected,

- competent - fully implements all competency opportunities,

- expert - is a model for others.

Figure 2. Efficiency of cooperation and principles of professional ethics.

It is worth noting that the stronger their beliefs about self-efficacy, the higher the goals are set for themselves by the people, and the stronger their commitment to the intended behaviour even in the face of increasing failures (Locke \& Latham, 1990). The sense of effectiveness expresses the image of the competence of the individual, its equipment in order to carry out the intended actions, moreover it differentiates people in terms of thinking, feeling and acting, influences the choice of situation, i.e. its rejection or acceptance depending on the effects (Juczyński, 2000). A strong sense of self-efficacy affects cognitive processes and intellectual achievement, encourages to invest greater effort and perseverance to choose more ambitious tasks. Low self-efficacy is associated with depression, anxiety, and helplessness (Schwarzer \& Fuchs, 1996).

The obtained results show that officers have a sense of dignity (most important for ethics), responsibility and conscientiousness and integrity in service. However, the last feature is treated very formally by them. In addition, they are calm, 
look good, know their professional roots and, above all, are willing to cooperate. The principles of professional ethics are considered important, but they translate into the efficiency of cooperation only to a certain extent. Perhaps among all the extension of the ethical code and the periodic assessment of compliance with ethical standards could have an impact on the discussed phenomenon.

Based on the abovementioned test results, it can be assumed that in border guards, the ethos of service is probably related to the educational-disciplinary process (service can be performed by a person who is willing to subordinate specific professional discipline) (Act, 1990, Article 61 (1) and 1a) and is clearly separated from the ethical issues in the overall and cultural aspect of the organization in general. For example, there are two different causes of corruption provided: a) lack of ethos of service; b) ethical formation crisis (Map of corruption threats, 2015, p. 12). An extensive and detailed catalogue of visible artefacts (e.g. ceremonial, uniforms), paying attention to particular values, among others the honour of the uniform is not correlated with the rather sparingly written code of ethics. In addition, e.g., the "whistleblower" function is mentioned in the examined documents, but there are no examples of using it in practice. This issue requires more detailed research, considering the complexity of the matter.

\section{Conclusions}

The link between cooperation efficiency (from the side of the officers) and the rules of professional ethics - so called praxeological ethics have been investigated and established. The results show that there is a link between these variables. Respondents believe that they work more effectively (knowingly), knowing and applying the principles of professional ethics. However, there are barriers in this regard, both from the characteristics of the respondents and from the characteristics of the organization that the respondents see and want to level. The obtained results of the research encourage to make the following practical conclusions.

The principles of professional ethics affect the effectiveness of the cooperation of officers to a certain extent. Hence the need to manage the culture of cooperation, mainly at the level of strengthening, monitoring and evaluating, rather than introducing rules from scratch.

It is necessary to shape a culture of cooperation based on the values and norms resulting from joint service, including the consistent introduction and application of tools for shaping ethical behaviours. The role of the prime minister is invaluable, and it should constitute a role model for officers as it still represents and disposes of means strengthening and perpetuating desirable behaviour. It is proposed therefore to:

- maintain relationships based on trust and mutual respect resulting from the authority of the leader; officers often mimic the behaviour of superiors, seeing patterns of behaviour in them, so the consistency of leadership at the leadership level has a great impact on the effects of ethical leadership, 
- broaden the ethical code with more prescriptive standards and comprehensive, understandable standards and rules of conduct in specific cases. If the organization does not indicate which behaviour is treated as ethical and which is unethical, there is a risk of the latter appearing,

- pay attention not only to the objectives but also to the means of their achievement, taking into account those subject to equivalent evaluation, ethical aspects,

- introduce periodic assessment of ethical standards,

- introduce ethical screening consisting of a strategic "screening" of the ethical condition of officers,

- make it clear that professional ethics is about behaviour both inside and outside of the service,

- provide training in the scope of professional ethics for all officers,

- examine the level of involvement of officers, their satisfaction,

- act in the field of stress prevention (including moral consequences resulting from, e.g. conflicts of values and norms),

- indicate a "whistle-blower," impartial ethical advisor,

- enable undertaking discussion on ethical issues,

- ensure feasibility, referring to conditions created by border guards to enable officers to meet normative expectations (time, funds, equipment, information and knowledge). If access to the mentioned items is impeded, the risk of unethical behaviour increases.

The analysis of the variables discussed does not, of course, exhaust all dimensions, useful for diagnosing organizational culture, probably one of the most difficult categories to define in organizational theory. It constitutes just a slice of it, providing many interesting data that may be the starting point for further empirical research.

\section{References}

Act (1990). Ustawa z 12 października 1990 r. o Straży Granicznej (tekst jedn. Dz. U. 1990, nr 78 poz. 462 ze zm.).

Bocheński, J.M. (1992). Współczesne metody myślenia. Poznań: Antyk.

Ciborowski, L. (2010). Wstęp. In W. Kieżun, L. Ciborowski, J. Wołejszo (eds.), Prakseologiczne aspekty zarządzania we współczesnych organizacjach publicznych, vol. I. Warszawa: Akademia Obrony Narodowej, pp. 5-6.

Edict (2014). Zarządzenie nr 54 Komendanta Głównego Straży Granicznej z dnia 17 kwietnia 2014 r., w sprawie nadania regulaminu organizacyjnego Komendzie Nadodrzańskiego Oddziału Straży Granicznej z siedzibą w Krośnie Odrzańskim (Dz. Urz. KGSG 2014.72).

Filipowicz, G. (2016). Zarządzanie kompetencjami. Perspektywa firmowa i osobista. Warszawa: Wolters Kluwer.

Gasparski, W. (2000). Wykłady z etyki biznesu. Warszawa: Wydawnictwo Wyższej Szkoły Przedsiębiorczości i Zarządzania im. Leona Koźmińskiego.

Górniak, J., \& Wachnicki, J. (2000). Pierwsze kroki w analizie danych SPSS PL for Windows. Kraków: SPSS Polska. 
Herman, A., Oleksyn, T., \& Stańczyk, I. (eds.) (2016). Zarządzanie respektujące wartości. Raport $z$ badań. Warszawa: Difin.

Hofstede, G. (2000). Kultury i organizacje. Zaprogramowanie umysłu. Warszawa: Polskie Wydawnictwo Ekonomiczne.

Huxham, Ch. (ed.) (1996). Creative Collaborative Advantage. London: Sage Publications.

Juczyński, Z. (2000). Poczucie własnej skuteczności - teoria i pomiar. Acta Universitatis Londziensis. Folia Psychologica, (4), 11-12.

Kieżun, W. (2005). O sprawną administrację publiczną. Ius et Lex, (1/III), 3-18.

Kożuch, B. (2004). Zarządzanie publiczne $w$ teorii i praktyce polskich organizacji. Warszawa: Placet.

Kożuch, B. (2011). Nauka o organizacji. Warszawa: CeDeWu.pl.

Kożuch, B. (2015). Zarządzanie publiczne jako teoria i praktyka. In B. Kożuch, Ł. Sułkowski (eds.), Instrumentarium zarządzania publicznego. Warszawa: Difin, pp. 23-38.

Kożuch, B., \& Sienkiewicz-Małyjurek, K. (2013). Mierzenie skuteczności współpracy międzyorganizacyjnej w zarządzaniu bezpieczeństwem publicznym. Studia Ekonomiczne Uniwersytetu Ekonomicznego, (68), 82-95.

Lank, E. (2007). Collaborative Advantage. London: Palgrave Macmillan.

Locke, E.A., \& Latham, G.R. (1990). A theory of goal setting and task performance. The Academy of Management Review, 16(2), 480-483.

Map of corruption threats (2015), retrieved from: file://C:/Users/Asus/Downloads/Mapa_Zagrozen_Korupcyjnych_w_Strazy_Granicznej\%20(1).pdf [accessed: 26.04.2016].

Mises, L. (2007). Ludzkie działanie. Traktat o ekonomii. Warszawa: Instytut Ludwiga von Misesa.

Nowak, E. (2009). Ile znaczą komponenty moralno-dyskursywne dla demokracji? In K.M. Cern, P.W. Juchacz, E. Nowak (eds.), Etyka życia publicznego. Poznań: Wydawnictwo Naukowe Instytutu Filozofii Uniwersytetu im. Adama Mickiewicza, pp. 31-42.

Rostkowski, T. (2012). Strategiczne zarządzanie zasobami ludzkimi w administracji publicznej. Warszawa: Wolters Kluwer.

Schwarzer, R., \& Fuchs, R. (1996). Self-efficacy and health behavior. In M. Conner, P. Norman (eds.), Predicting Health Behavior. Buckingham: Open University Press, pp. 163-196.

Schwarzer, R., Jerusalem, M., \& Juczyński, Z. (2009). Narzędzia pomiaru w promocji $i$ psychologii zdrowia. Warszawa: Pracownia Testów Psychologicznych.

Sienkiewicz-Małyjurek, K. (2015). Skuteczne zarządzanie kryzysowe. Warszawa: Difin.

Sikorski, Cz. (2014). Dysonans kulturowy a zarządzanie kulturą organizacyjną. In J. Różański, J. Czarnecki (eds.), Zarządzanie współczesnymi organizacjami. Łódź: Wydawnictwo Wydziału Zarządzania Uniwersytetu Łódzkiego, pp. 73-86.

Sułkowski, Ł. (2015). Kultura organizacji publicznej. In B. Kożuch, Ł. Sułkowski (eds.), Instrumentarium zarządzania publicznego. Warszawa: Difin, pp. 92-115.

Szaban, J.M. (2011). Zarzadzanie zasobami ludzkimi $w$ biznesie $i w$ administracji publicznej. Warszawa: Difin.

The Border Guard in the number (2016), retrieved from: https://www.strazgraniczna.pl/pl/ aktualnosci/4924,Straz-Graniczna-w-liczbach.html [accessed: 10.04.2016].

\section{Note about the Author}

Lilla MŁodziK - academic teacher of the University of Zielona Góra, Ph.D. in economic sciences in the field of human management, scientific interests - psychosocial aspects of management of an organization (public), conditions of social behaviour in the context of functional relations, cooperation and communication and relations of power. 